\title{
Article \\ The relationship between type $D$ personality and The stress level of life events, personality traits and anxiety sensitivity in people with breast cancer
}

\author{
Atena Pasha $^{* 1}$, Seyed Abdolmajid Bahrainian ${ }^{2}$, Hojjatollah Farahani ${ }^{3}$ \\ ${ }^{1}$ Department of Psychology, Tehran Medical Sciences, Islamic Azad University, Tehran, Iran; \\ atena.pasha@yahoo.com \\ ${ }^{2}$ Department of Psychology, Tehran Medical Sciences, Islamic Azad University, Tehran, Iran; \\ majid.bahrainian@gmail.com \\ ${ }^{3}$ Department of Psychology, Tarbiat Modares University (TMU), Tehran, Iran; h.farahani@modares.ac.ir \\ * Corresponding author: atena.pasha@yahoo.com
}

\begin{abstract}
Background and Aim: Cancer is a disease characterized by uncontrolled cell growth and invasion of tissues. It seems that personality differences and psychological factors are important factors that lead to different reactions to cancer. Therefore, the main purpose of the present study was to investigate the relationship between type D, stress level of life events, personality traits, and anxiety sensitivity in people with breast cancer attending to Tehran Bu-ali Hospital. Methods: The study was a correlational study in which 100 cancer patients referred to Bu-ali Hospital in Tehran, selected by the available sampling method from April to June 2018. The tools used included the Denollet DS-14 Type D Questionnaire, the Paykel Life events Questionnaire, the Eysenck Personality Questionnaire, the ASI Anxiety Scale, Floyd et al., Data analysis in this study is taken place by using SPSS software, two descriptive levels (percentage, frequency, etc.) and regression. Results: The study results showed that there is a relationship between type D personality with stress of life events, neurosis, extraversion, and psychopath dimensions of personality and anxiety sensitivity in breast cancer patients. Conclusion: Psychological factors play a role in the incidence and exacerbation of breast cancer, and ultimately patients with personality type D and personality traits such as psychosis and high anxiety sensitivity and more stress of life events show more symptoms.

Keywords: Type D, Personality, Stress of Life Events, Anxiety Sensitivity, Breast Cancer.

\section{Introduction}

Cancer is a disease that begins in one or more cells, and these cells begin to multiply and form a compact cell mass or a gland (1). Breast cancer is the most common type of cancer among women in developing countries. Over the past four decades, the increase in the incidence of breast cancer has made it one of the most malignant among Iranian women, affecting Iranian women a decade earlier than their counterparts in developed countries (2). Breast surgeries can lead to deformity or removal of one or both breasts. Surgical procedures affect various aspects of a woman's psychosocial functioning, such as identity, trust, mood, sexual desire, self-satisfaction, and quality of life (3). Body image problems are associated with stress, depression, withdrawal from social relationships, and anxiety about not being accepted by one's spouse. They compare themselves to before getting cancer and their therapies and as a result, their feelings of failure, depression, and anxiety increase (4). Mehri Nejad, Khosravani Shariati, and Hosseini Abad Shapouri (5) concluded in a study that women with breast cancer feel more anxious which is different from the anxiety that healthy women experience. women with cancer have experienced more frequency of anxiety than healthy people. This means that sick women find the incidents much more threatening, and at the same
\end{abstract}


time, they have experienced more quarrels with their husbands and the death of family members. Research has been conducted on personality traits and their effect on the development and spread of cancer, with data suggesting the role of psychosocial factors that are most vulnerable to getting cancer. Therefore, the main aim of the present study was to investigate the relationship between type D, stress level of life events, personality traits and anxiety sensitivity in people with cancer who referred to Bu-ali Hospital in Tehran.

type D personality is derived from the view of Denollet et al., (6) in classifying human personality dimensions, which has two components: negative affectivity and social inhibition, and has been confirmed as a determinant of emotional turmoil in psychosomatic patients, including cancer patients. Accordingly, negative affectivity is characterized by a desire to express negative emotions. People with high negative affectivity are more likely to experience negative affectivity at all times, regardless of the situation (6). Social inhibition is also characterized by a persistent tendency to inhibit emotional and behavioral experiences in social interactions. People with high social inhibition are more likely to prevent others from reacting negatively by overemphasizing self-expression (not expressing their views and characteristics) (7). A study by Floortje et al. (8) of 3080 cancer-surviving patients found that $19 \%$ of these individuals had type D personality. It has also been shown that type D personality has a negative relationship with mental health status. Adults with personality type D experience more symptoms of depression and anxiety than non-type D people (9). They are also more likely to experience stress than non-type D people (10). Studies have shown that personality type D is a predictor of cancer spread (11). Moles et al., Showed that type D personality has a negative effect on the recovery process of people with cancer (12).

It has also been shown that the susceptibility to some viral infections increases following various psychological pressures. One of the mechanisms of cancer is the failure of the body's immune system, led by lymphocytes. In the Biological Psychological Approach, it is assumed that social-psychological factors can affect the body's immune system and thus predispose a person to cancer. Therefore, considering the role of personality traits in the incidence of diseases, especially type D personality, stressful life events and anxiety sensitivity, different results in previous studies, and also the existence of few studies in this field, especially in Iran, the main question of this study is to see if there is any relationship between type D personality with the stress level of life events, personality traits and anxiety sensitivity in people with breast cancer in Bu-Ali Hospital in Tehran in 2018, which can leads to helping people with cancer through psychological interventions and offering psychological treatment courses for people with cancer in clinics and Hospitals. Therefore, the present study hypothesizes that there is a relationship between type D with the stress level of life events, personality traits, and anxiety sensitivity in people with breast cancer referred to Bu-Ali Hospital in Tehran.

\section{Materials and Methods}

The research method is correlational. The statistical population of the study includes all people with breast cancer who refer to Bu-Ali Hospital in Tehran in April, May, and June of 2018. The sample size of this study was calculated based on Cochran's formula for limited communities and assumed a 5\% error and a maximum tolerable error of 5\% of the change coefficient. According to the mentioned cases, the volume of the sample was determined to be 96 people, which was selected to ensure 100 samples, and the samples were selected among the patients of Bu-ali Hospital in Tehran. After receiving the introduction letter from the Research Vice-Chancellor of Tehran Medical sciences, Islamic Azad University and presenting it to the Vice-Chancellor of the Health and Medical Network of Tehran's Bu-Ali Hospital, and obtaining the IR.IAU.TMU.REC.2018.099 ethical code and obtaining written consent from individuals with breast cancer, the data were collected by the patients completing the questionnaires. Patients referred to the Department of Chemotherapy were first referred to a clinical psychologist. Based on the level of willingness to participate in the research, after a brief explanation for the them and emphasizing the confidentiality of the information, they were asked to read the research consent and entered the study if they wanted and had the entry and exit criteria. The data were analyzed using the D14 Personality Type Questionnaire (6), the Paykel life events questionnaire (13), the Eysenck Personality Traits Questionnaire (14), and the ASI Anxiety Sensitivity Questionnaire (15). For this purpose, the questionnaires were provided to the patients and they were asked to answer the questionnaires at the same time, and if there was a problem, the examiner would help them with the necessary explanations. Criteria for entering the study included the age of 20 or older and the ability to read and write, and the criteria for leaving the study included people with other physical illnesses, the illiterate, and people under the age of 20.

\section{Data analyzing method}


In this research, to analyze the data, first, descriptive statistics indicators such as frequency tables and numerical indicators such as mean and standard deviation, the study population, and research components are described using descriptive statistics. Then, by using correlation analysis and fitting regression models, the relationships between the research variables will be analyzed. In order to fit the regression model, a step-by-step method has been used. In this method, first, by comparing between the predictor variables in terms of the significance of the variable that has the lowest significant level and has a significant level of less than 0.05 , it enters the model, then the next variable is examined with the presence of the previous variable, and so on until all the predictor variables are examined. Also, in each step, by adding a new variable to the model, a test will be performed to remove the previous variables, but with an error of 0.10 .

D14 Personality Type Questionnaire (6):

The questionnaire consists of 14 questions and has two subscales of negative affectivity (NA) and social inhibition (SI), each of them has 7 criteria. The answers are on a Likert scale. Each respondent responds to this scale as "never," "rarely," "sometimes, often, and always." In a study conducted by Zoljnahi and Vafaie (16) in Iran, the internal consistency of the negative subscale of negative affectivity was 0.77 and the internal consistency of the subscale scale of social inhibition was 0.69 .

Paykel Life Events Questionnaire (13):

The questionnaire has 65 life events which the subject must identify the events he or she has personally experienced in the past two years and in a separate column, determine terms of the amount of stress he or she has undergone by each events in a scale of five Likert options (none, low, medium, high, intense). This questionnaire is more efficient in terms of comprehensiveness and content validity than other scales.

Eysenck Personality Questionnaire (14)

This questionnaire has 90 questions and four scales of extroversion, neurosis, psychosis, and lying, and measures the three basic dimensions of personality. The subject must express his or her opinion on each of the questions with a yes or no answer. In order to determine the validity and reliability of this questionnaire, Eysenck implemented it on a single group at two different times and obtained its validity and reliability. Internal validity coefficient (Cronbach's alpha ( $\mathrm{P}=0.78$ for men, and $\mathrm{P}=0.76$ for women) was obtained. In Iran, this questionnaire was presented by Baraheni et al., (17) on some Iranian girls and boys (12-18 years old), has been standardized and its validity and reliability have been reported in high-level studies.

Anxiety sensitivity scale

Anxiety Sensitivity Questionnaire is a 16-item self-report questionnaire (ASI) based on a five-point Likert scale (very low $=0$ to very high $=4$ ). Each statement reflects the fact that feelings of anxiety are experienced in an unpleasant way and have the potential to lead to traumatic consequences. The degree of fear experience is determined by the symptoms of anxiety with higher scores. The score range is between 0 and 64 (15). The examination of the psychometric properties of this scale has shown its high internal stability (alpha between 0.80 and 0.90).

\section{Results}

Based on the contents of Table 1, the mean and standard deviation of negative affectivity of type D are 22.95 and 4.59, respectively, and the mean and standard deviation of social inhibition of type D are 19.65 and 5.536, respectively, as well as the mean and standard deviation. The stress of life events is 75.19 and 42.04, respectively, the personality neurotic dimension is 10.95 and 3.47, respectively, the personality extroversion is 10.79 and 3.49 , respectively, and the personality psychosis is 6.99 and 3.64 and anxiety sensitivity are 3.19 and 1.48 , respectively.

The contents of Table 2 show that the correlation coefficient between negative affectivity of type D with the stress level of life events, personality neuroticism dimension, personality extroversion dimension, personality psychosis dimension and anxiety sensitivity were $0.333(\mathrm{p}<0.05)$, respectively, $0.615(\mathrm{p}<0.05),-0.421(\mathrm{p}<0.05), 0.708(\mathrm{p}<0.05)$ and $0.335 \quad(\mathrm{p} \quad<0.05)$. Table 2 also shows that the correlation coefficient between social inhabitation of type D with the stress level of life events, personality neuroticism dimension, personality extroversion dimension, personality psychosis dimension and anxiety sensitivity were respectively, $0.242(\mathrm{p}<0.05)(0.451(\mathrm{p}<0.05), 0.95(\mathrm{p}<0.05), 0.505(\mathrm{p}<0.05)$ and $0.268(\mathrm{p}$ $<0.05)$.

According to the information in Table 3, the correlation coefficient for the linear combination of negative affectivity 
of type D and social inhabitation of type D with the stress level of life events of people with breast cancer is 0.333 , which is significant at the level of 0.001 . Thus, approximately $11 \%$ of the variance in the stress level of life events in people with breast cancer is explained by predictor variables.

The beta coefficient for each of the predictor variables and their significance is also visible. As shown in Table 4, according to the results of the step-by-step regression analysis, among the predictor variables, negative affectivity of type $\mathrm{D}$ is the best predictor of the stress level of life events in people with breast cancer. The correlation coefficient for this predictor variable is $r=0.336$ and the determination coefficient is $0.2=0.113$, which is significant at the level of $\mathrm{P}<0.001$.

As shown in Table 5, according to the results of regression analysis by step-by-step method, among the predictor variables, negative affectivity of type $\mathrm{D}$ is the best predictor of Neurosis dimension of the personality of people with breast cancer. The multiple correlation coefficient for the linear combination of predictor variables is $\mathrm{MR}=0.615$ and $\mathrm{RS}=0.378$, which is significant at the $\mathrm{P}<0.001$ level.

As shown in Table 6, according to the results of regression analysis by step-by-step method, among the predictor variables, Type D social inhibition is the best predictor of extroversion dimension of personality in people with breast cancer. The multiple correlation coefficient for the linear combination of predictor variables is $\mathrm{MR}=0.59$ and $\mathrm{RS}=$ 0.348 , which is significant at the $\mathrm{P}<0.001$ level.

As shown in Table 7, according to the results of the step-by-step regression analysis, among the predictor variables, negative affectivity of type $\mathrm{D}$ is the best predictor of psychosis dimension of personality of people with breast cancer. The multiplicity correlation coefficient for this predictor variable is $\mathrm{MR}=0.708$ and $\mathrm{RS}=0.502$, which is significant at the $\mathrm{P}<0.001$ level.

Table 1. mean, standard deviation, maximum and lowest scores of subjects in predictor variables and components of criterion variables

\begin{tabular}{|l|l|l|l|}
\hline Standard deviation & Mean & $\begin{array}{l}\text { Index } \\
\text { Component }\end{array}$ & \\
\hline 4.59 & 22.59 & Negative affectivity of type D & 1 \\
\hline 5.53 & 19.56 & Social inhabitation type D & 2 \\
\hline 4.2 & 75.19 & The stress level of life events & 3 \\
\hline 3.47 & 10.95 & Neuroticism Dimensions of Personality & 4 \\
\hline 3.49 & 10.79 & extroversion Dimensions of Personality & 5 \\
\hline 3.64 & 6.99 & psychoticism Dimensions of Personality & 6 \\
\hline 1.48 & 3.19 & Anxiety sensitivity & 7 \\
\hline
\end{tabular}

Based on the contents of Table 1, the mean and standard deviation of negative affectivity of type D are 22.95 and 4.59, respectively, and the mean and standard deviation of social inhibition of type D are 19.65 and 5.536, respectively, as well as the mean and standard deviation. The stress of life events is 75.19 and 42.04, respectively, the personality neurotic dimension is 10.95 and 3.47 , respectively, the personality extroversion is 10.79 and 3.49 , respectively, and the personality psychosis is 6.99 and 3.64 and anxiety sensitivity are 3.19 and 1.48 , respectively.

Table 2. Correlation of negative affectivity of type D and social inhabitation of type D with variable stress level of life events, personality traits and anxiety sensitivity

\begin{tabular}{|c|c|c|c|c|c|c|}
\hline $\begin{array}{l}\text { Anxiety } \\
\text { sensitivity }\end{array}$ & $\begin{array}{l}\text { psychoticism } \\
\text { Dimensions }\end{array}$ & $\begin{array}{l}\text { extroversion } \\
\text { Dimensions of }\end{array}$ & $\begin{array}{l}\text { Neuroticism } \\
\text { Dimensions of }\end{array}$ & $\begin{array}{l}\text { The } \\
\text { stress }\end{array}$ & \multicolumn{2}{|c|}{$\begin{array}{l}\text { Property variable } \\
\text { Predictable variable }\end{array}$} \\
\hline .335 & .708 & -.421 & .615 & .333 & $\begin{array}{l}\text { The } \\
\text { correlation } \\
\text { coefficient }\end{array}$ & \multirow[t]{2}{*}{$\begin{array}{l}\text { Negative } \\
\text { affectivity }\end{array}$} \\
\hline .001 & .001 & .001 & .001 & .001 & $\begin{array}{l}\text { The } \\
\text { significance } \\
\text { level }\end{array}$ & \\
\hline-.268 & -.505 & .590 & -.451 & -.242 & $\begin{array}{l}\text { The } \\
\text { correlation } \\
\text { coefficient }\end{array}$ & $\begin{array}{l}\text { Social } \\
\text { inhabitation }\end{array}$ \\
\hline
\end{tabular}




\begin{tabular}{|l|l|l|l|l|l|l|}
\hline .001 & .001 & .001 & .001 & .015 & $\begin{array}{l}\text { The } \\
\text { significance } \\
\text { level }\end{array}$ & \\
\hline
\end{tabular}

The contents of Table 2 show that the correlation coefficient between negative affectivity of type D with the stress level of life events, personality neuroticism dimension, personality extroversion dimension, personality psychosis dimension and anxiety sensitivity were $0.333(\mathrm{p}<0.05)$, respectively, $0.615(\mathrm{p}<0.05),-0.421(\mathrm{p}<0.05), 0.708(\mathrm{p}<0.05)$ and $0.335(\mathrm{p}<0.05)$.

Table 2 also shows that the correlation coefficient between social inhabitation of type D with the stress level of life events, personality neuroticism dimension, personality extroversion dimension, personality psychosis dimension and anxiety sensitivity were respectively, $0.242(\mathrm{p}<0.05)(0.451(\mathrm{p}<0.05), 0.95(\mathrm{p}<0.05), 0.505(\mathrm{p}<0.05)$ and $0.268(\mathrm{p}$ $<0.05)$.

Table 3. Results of Multiple Regression Analysis of Negative affectivity of Type D and Social inhabitation of Type $\mathrm{D}$ with Components of the Stress of Life Events of People with Breast Cancer by Step-by-Step Method

\begin{tabular}{|c|c|c|c|c|c|c|c|c|c|}
\hline \multirow[b]{2}{*}{ Result } & \multicolumn{4}{|c|}{ Features of the regression model } & \multirow[b]{2}{*}{$\begin{array}{l}\text { The } \\
\text { significa } \\
\text { nce level }\end{array}$} & \multirow[b]{2}{*}{$\begin{array}{l}\text { Statisti } \\
\text { cs F }\end{array}$} & \multirow[b]{2}{*}{$\begin{array}{l}\text { Determ } \\
\text { ination } \\
\text { coeffici } \\
\text { ent }\end{array}$} & \multirow[b]{2}{*}{$\begin{array}{l}\text { Correlati } \\
\text { on } \\
\text { coefficie } \\
\text { nt }\end{array}$} & \multirow[b]{2}{*}{$\begin{array}{l}\text { Predictable } \\
\text { variable }\end{array}$} \\
\hline & $\begin{array}{l}\text { The } \\
\text { signif } \\
\text { icanc } \\
\text { e } \\
\text { level }\end{array}$ & $\begin{array}{l}\text { istic } \\
\text { s t }\end{array}$ & $\begin{array}{l}\text { Variable } \\
\text { coefficie } \\
\text { nt }\end{array}$ & $\begin{array}{l}\text { Consta } \\
\mathrm{nt}\end{array}$ & & & & & \\
\hline $\begin{array}{l}\text { It is } \\
\text { significa } \\
\text { nt }\end{array}$ & .001 & 3.49 & 3.03 & 6.54 & .001 & 12.19 & .113 & .333 & $\begin{array}{l}\text { Negative } \\
\text { affectivity }\end{array}$ \\
\hline
\end{tabular}

According to the information in Table 3, the correlation coefficient for the linear combination of negative affectivity of type D and social inhabitation of type D with the stress level of life events of people with breast cancer is 0.333 , which is significant at the level of 0.001 . Thus, approximately $11 \%$ of the variance in the stress level of life events in people with breast cancer is explained by predictor variables.

The beta coefficient for each of the predictor variables and their significance is also visible. As shown in Table 4, according to the results of the step-by-step regression analysis, among the predictor variables, negative affectivity of type D is the best predictor of the stress level of life events in people with breast cancer. The correlation coefficient for this predictor variable is $r=0.336$ and the determination coefficient is $0.2=0.113$, which is significant at the level of $\mathrm{P}<0.001$.

Table 4. Results of Multiple Regression Analysis of Negative affectivity of Type D and Social inhabitation of Type D with Component of personality neuroticism dimension of People with Breast Cancer by Step-by-Step (Step wise)

\begin{tabular}{|c|c|c|c|c|c|c|c|c|c|}
\hline \multirow[b]{2}{*}{ Result } & \multicolumn{4}{|c|}{ Features of the regression model } & \multirow[b]{2}{*}{$\begin{array}{l}\text { The } \\
\text { significa } \\
\text { nce level }\end{array}$} & \multirow[b]{2}{*}{$\begin{array}{l}\text { Statisti } \\
\text { cs F }\end{array}$} & \multirow{2}{*}{$\begin{array}{l}\text { Determ } \\
\text { ination } \\
\text { coeffici } \\
\text { ent }\end{array}$} & \multirow{2}{*}{$\begin{array}{l}\text { Correlati } \\
\text { on } \\
\text { coefficie } \\
\text { nt }\end{array}$} & \multirow[b]{2}{*}{$\begin{array}{l}\text { Predictabl } \\
\text { e variable }\end{array}$} \\
\hline & $\begin{array}{l}\text { The } \\
\text { significa } \\
\text { nce level }\end{array}$ & $\begin{array}{l}\text { Statist } \\
\text { ics t }\end{array}$ & $\begin{array}{l}\text { Variable } \\
\text { coefficie } \\
\text { nt }\end{array}$ & $\begin{array}{l}\text { Consta } \\
\text { nt }\end{array}$ & & & & & \\
\hline $\begin{array}{l}\text { It is } \\
\text { significant }\end{array}$ & .001 & 7.71 & .465 & .455 & .001 & 59.48 & .378 & .615 & $\begin{array}{l}\text { Negative } \\
\text { affectivity }\end{array}$ \\
\hline
\end{tabular}

As shown in Table 4, according to the results of regression analysis by step-by-step method, among the predictor variables, negative affectivity of type $\mathrm{D}$ is the best predictor of personality neuroticism dimension in people with breast cancer. The correlation coefficient for the linear composition of the predictor variables is $\mathrm{R}=0.615$ and $\mathrm{RR}=$ 0.378 , which is significant at the $\mathrm{P}<0.001$ level.

Table 5. Results of Multiple Regression Analysis of Negative affectivity of Type D and Social inhabitation of Type D with the Subsequent Component of Personality Outbreaks of People with Breast Cancer by Step wise

\begin{tabular}{|l|l|l|l|l|l|l|l|l|l|}
\hline \multirow{4}{*}{ Result } & \multicolumn{2}{|l|}{ Features of the regression model } & The \\
\cline { 2 - 7 } & $\begin{array}{l}\text { The } \\
\text { significa } \\
\text { nce level }\end{array}$ & $\begin{array}{l}\text { Statist } \\
\text { ics t }\end{array}$ & $\begin{array}{l}\text { Variable } \\
\text { coefficie } \\
\text { nt }\end{array}$ & $\begin{array}{l}\text { Consta } \\
\text { nt }\end{array}$ & $\begin{array}{l}\text { significa } \\
\text { nce level }\end{array}$ & $\begin{array}{l}\text { Statisti } \\
\text { cs F }\end{array}$ & $\begin{array}{l}\text { Determ } \\
\text { ination } \\
\text { coeffici } \\
\text { ent }\end{array}$ & $\begin{array}{l}\text { Correlati } \\
\text { on } \\
\text { coefficie } \\
\text { nt }\end{array}$ & $\begin{array}{l}\text { Predicta } \\
\text { ble } \\
\text { variable }\end{array}$ \\
\hline
\end{tabular}




\begin{tabular}{|l|l|l|l|l|l|l|l|l|l|}
\hline $\begin{array}{l}\text { It is } \\
\text { significant }\end{array}$ & .001 & 7.22 & .372 & 3.51 & .001 & 52.25 & .348 & .59 & $\begin{array}{l}\text { Negative } \\
\text { affectivit } \\
\text { y }\end{array}$ \\
\hline
\end{tabular}

As shown in Table 5, according to the results of the step-by-step regression analysis, among the predictor variables, Type D social inhibition is the best predictor of extroversion dimension of personality in people with breast cancer. The correlation coefficient for the linear composition of the predictor variables is $\mathrm{R}=0.059$ and $\mathrm{RR}=0.348$, which is significant at the $\mathrm{P}<0.001$ level.

Table 6. Results of Multiple Regression Analysis of Negative affectivity of Type D and Social Control of Type D with personality psychosis dimension of People with Breast Cancer by Step-by-Step Method

\begin{tabular}{|c|c|c|c|c|c|c|c|c|c|}
\hline \multirow[b]{2}{*}{ Result } & \multicolumn{4}{|c|}{ Features of the regression model } & \multirow[b]{2}{*}{$\begin{array}{l}\text { The } \\
\text { significa } \\
\text { nce level }\end{array}$} & \multirow[b]{2}{*}{$\begin{array}{l}\text { Statisti } \\
\text { cs F }\end{array}$} & \multirow{2}{*}{$\begin{array}{l}\text { Determ } \\
\text { ination } \\
\text { coeffici } \\
\text { ent }\end{array}$} & \multirow{2}{*}{$\begin{array}{l}\text { Correlati } \\
\text { on } \\
\text { coefficie } \\
\text { nt }\end{array}$} & \multirow[b]{2}{*}{$\begin{array}{l}\text { Predicta } \\
\text { ble } \\
\text { variable }\end{array}$} \\
\hline & $\begin{array}{l}\text { The } \\
\text { significa } \\
\text { nce level }\end{array}$ & $\begin{array}{l}\text { Statist } \\
\text { ics t }\end{array}$ & $\begin{array}{l}\text { Variable } \\
\text { coefficie } \\
\text { nt }\end{array}$ & $\begin{array}{l}\text { Consta } \\
\text { nt }\end{array}$ & & & & & \\
\hline $\begin{array}{l}\text { It is } \\
\text { significant }\end{array}$ & .001 & 9.93 & .562 & -5.7 & .001 & 98.76 & .502 & .708 & $\begin{array}{l}\text { Negative } \\
\text { affectivit } \\
\mathrm{y}\end{array}$ \\
\hline
\end{tabular}

As shown in Table 6, according to the results of the step-by-step regression analysis, among the predictor variables, negative affectivity of type $\mathrm{D}$ is the best predictor of psychosis dimension of personality in people with breast cancer. The correlation coefficient for this predictor variable is $\mathrm{R}=0.708$ and $\mathrm{RR}=0.502$, which is significant at the level of $\mathrm{P}$

$<0.001$.

Table 7. Results of Multiple Regression Analysis of Type D Negative affectivity and Type D Social inhabitation with Components of Anxiety Sensitivity in People with Breast Cancer by Stepwise Step

\begin{tabular}{|c|c|c|c|c|c|c|c|c|c|}
\hline \multirow[b]{2}{*}{ Result } & \multicolumn{4}{|c|}{ Features of the regression model } & \multirow[b]{2}{*}{$\begin{array}{l}\text { The } \\
\text { significa } \\
\text { nce level }\end{array}$} & \multirow[b]{2}{*}{$\begin{array}{l}\text { Statisti } \\
\text { cs F }\end{array}$} & \multirow{2}{*}{$\begin{array}{l}\text { Determ } \\
\text { ination } \\
\text { coeffici } \\
\text { ent }\end{array}$} & \multirow{2}{*}{$\begin{array}{l}\text { Correlati } \\
\text { on } \\
\text { coefficie } \\
\text { nt }\end{array}$} & \multirow[b]{2}{*}{$\begin{array}{l}\text { Predicta } \\
\text { ble } \\
\text { variable }\end{array}$} \\
\hline & $\begin{array}{l}\text { The } \\
\text { significa } \\
\text { nce level }\end{array}$ & $\begin{array}{l}\text { Statist } \\
\text { ics t }\end{array}$ & $\begin{array}{l}\text { Variable } \\
\text { coefficie } \\
\text { nt }\end{array}$ & $\begin{array}{l}\text { Consta } \\
\text { nt }\end{array}$ & & & & & \\
\hline $\begin{array}{l}\text { It is } \\
\text { significant }\end{array}$ & .001 & 3.51 & .108 & .751 & .001 & 12.35 & .112 & .335 & $\begin{array}{l}\text { Negative } \\
\text { affectivit } \\
\text { y }\end{array}$ \\
\hline
\end{tabular}

As shown in Table 7, according to the results of the step-by-step regression analysis, among the predictor variables, type D negative affectivity is the best predictor of anxiety sensitivity in people with breast cancer. The correlation coefficient for this predictor variable is $R=0.0335$ and $R R=0.112$, which is significant at the $P<0.001$ level.

\section{Discussion}

The findings show that there is a significant positive relationship (0.333) between type D and the stress level of life events in people with breast cancer. These findings are supported by a number of studies, including; Denollet (6), Holmes \& Rahe (18), Vafaei (19), Mirzaei et al., (20), Luecken, Compass (21). According to Holmes and Rahe (18), dealing with a large number of stressful situations can have adverse consequences for mental health in a short period of time. All life changes, including marriage, the death of a family member, changes in daily working hours, and even changes in vehicle traffic hours are stressful, and if the stress level exceeds the body's ability to adapt, it can lead to illness. The results of the study of Hashemi and Peymannia (22) showed that There is a relationship between type D personality and the perceived stress with health behavior $(\mathrm{p}<0.05$ and $\mathrm{r}=0.34)$ and $(\mathrm{P}<0.001)$ and $\mathrm{r}=-0.56)$. Vafaei (19) found in his study in 100 cancer patients that life stresses had a significant effect on the recurrence of leukemia and men had higher levels of stress and there are higher stress levels in both sexes between the ages of 34 to 46 . In people with cancer, life expectancy scores have been significantly higher than healthy people. Regarding the relationship between stress and cancer, it is related to behavioral changes that are caused by stress in a person and affect his health. In fact, people who show high levels of stress are more likely to engage in behaviors that increase their chances of getting sick, such as stress, increased smoking, alcohol consumption, and reduced sport exercises. 
Another explanation is related to changes in the immune system. Improper mental stress interferes with the body's immune system, allowing cancer cells that are always present in the body to grow and multiply. On the other hand, lymphocytes are responsible for finding and reducing malignant cells. In the meantime, stress reduces the ability of lymphocytes to increase the risk of cancerous tumors. Also, job loss, social isolation, economic problems, spending too much time on chemotherapy or radiotherapy, treatment costs, and adverse performance are stressors that can predispose cancer patients to mental disorders.

Research has also shown that there is a significant positive relationship between type D and personality traits of people with breast cancer $(0.615,0.9090$, and 0.708). These findings are supported by a number of studies, including; Clerk, Philippe (23), Margaret et al., (24), Nakaya, Tsubono, Nishini (25) match. The research findings of Margaret et al., (24) indicate that high levels of pessimism, introversion, loneliness, and isolation, excessive expectations of others, and non-acceptance of responsibility for the emotional states of incurable physical patients (cancer, MS, etc.) are considered. In some studies, no relationship has been reported between personality traits and the risk of cancer and its progression (25). The explanation given for the higher prevalence of introversion in cancer patients than for normal individuals may be related to the fact that introverts are not socially demanding and have strong social relationships with others, often preferring to be alone with others. Due to the above reasons and due to loneliness, introverts feel more stressed, which in itself can be the cause of cancer. Another explanation is the lack of expression or at least the weakness of introverts in this area. In fact, introverts are far less likely than extroverts to express and summon their inner anxieties, anger, and emotions, which is why they are more prone to cancer because not expressing negative emotions is the cause of cancer.

According to the research findings, it was found that there is a significant positive relationship between type D and anxiety sensitivity of people with breast cancer (0.335). These findings are related to many studies, including; Bijari (26), De Valck et al., (7), Denollet, (6), Pedersen, Yegensky, Smith, Shepak and Denollet, (9) Zvolensky, Feldener, Lynn Feldner, Bon Miller, McLeish, and colleagues (27), Kashdan, Byrus, Forsyth, and Esther, (28). Bijari (26) showed that women with breast cancer are characterized by such features as denial and suppression of emotions, especially anger, high tolerance for non-expression, defensiveness, and anti-excitability. This trait eventually leads to feelings of hopelessness and depression. Also, women with breast cancer are significantly more likely to use emotionoriented coping techniques (avoidance, restraint, avoidance escape) in the study of De Valck et al., (7), with 6 to 10 years of follow-up in people with coronary heart disease. The type D personality independently, predicting significant cardiac and non-cardiac events such as cancer, fatigue symptoms, and depressed emotions. In general, in explaining the research results, it can be said that psychological factors play a role in the incidence and exacerbation of breast cancer, and finally patients with type D personality and personality traits such as psychosis, and high anxiety sensitivity, and more stress of life events can lead the disease. This issue will lead to a more intense reaction and put the person in a general state of dissatisfaction and their physical and mental condition will get worse day by day. Therefore, it can be said that psychological factors play a role in the occurrence and exacerbation of breast cancer, and thus psychological strategies are effective in preventing and treating this disease.

One of the limitations of this research is the lack of new research and theoretical literature in the field of personality type D, along with access to reliable sources, lack of one-handedness in terms of age, education, and gender, and paper-based tools. Also, this study has examined only patients with breast cancer in Tehran's Bu-ali Hospital, so generalization of the results to other patients in other cities should be done with caution. to verify the findings of the present study, it is suggested that other studies be conducted in other cities, various cultural, social, and economic contexts, and other psychosomatic disorders and be compared with patients with breast cancer. Future research, intervention factors such as economic status, marital status, gender, and level of education in breast cancer patients should be considered.

\section{Author Contributions}

\section{Atena Pasha}

Substantial contributions to the conception of the work, Drafting the work and revising it critically for important intellectual content, Agreement to be accountable for all aspects of the work in ensuring that questions related to the accuracy or integrity of any part of the work are appropriately investigated and resolved.

\section{Seyyed Majid Bahrainian}

Substantial contributions to the conception of the work, Final approval of the version to be published

\section{Hojjatolah Farahani}

Substantial contributions to the conception of the work, the acquisition, analysis, and interpretation of data for the work.

Funding: This research received no external funding. 
Conflicts of Interest: All authors declare no conflicts of interest.

\section{References}

1. Bashirpoor KH. The comparison of personality trait, stress and depression in cancer patients and normal people. (Dissertation) Tabriz: Tabriz University; 2007. (Persian)

2. Pedram M, Mohammadi M, NaziriGh, Aiinparast N. The effectiveness of cognitive behavioral group therapy on treatmentanxity, depression and hope creation in women with breast cancer. Scientific Journal Management System 1389; 1(4): 61-75.

3. Helms RL, O'Hea EL, Corso M. Body image issues in women with breast cancer. Psychology, Health and medicine. 2008 May 1;13(3):313-25.

4. Moreira H, Canavarro MC. A longitudinal study about the body image and psychosocial adjustment of breast cancer patients during the course of the disease. European journal of oncology nursing. 2010 Sep 1;14(4):26370.

5. Mehrinejad A, Khosravani H, Hosseini M. Compare experienced stress womenwith breast cancerand healthy women. Daneshvar Raftar 1389; 17(43), 49-56.

6. Denollet J. DS14: standard assessment of negative affectivity, social inhibition, and Type D personality. Psychosomatic medicine. 2005 Jan 1;67(1):89-97.

7. De Valck CF, Denollet J, Wuyts FL, Van De Heyning PH. Increased handicap in vertigo patients with a typeD personality. Audiological Medicine. 2007 Jan 1;5(3):169-75.

8. Floortje M, Melissa SY. Thong, Lonneke V. vandePoll Franse, Jan AR, Denollet J. Type D (distressed) personality is associated with poor quality of life and mental health among 3080 cancer survivors. Journal of Affective Disorders. 2012; 136, 26-34.

9. Pedersen SS, Yagensky A, Smith OR, Yagenska O, Shpak V, Denollet J. Preliminary evidence for the crosscultural utility of the type D personality construct in the Ukraine. International journal of behavioral medicine. 2009 Jun 1;16(2):108.

10. Williams L, O'Connor RC, Howard S, Hughes BM, Johnston DW, Hay JL, O'Connor DB, Lewis CA, Ferguson E, Sheehy N, Grealy MA. Type-D personality mechanisms of effect: the role of health-related behavior and social support. Journal of psychosomatic research. 2008 Jan 1;64(1):63-9.

11. Denollet J, Conraads VM, Brutsaert DL, De Clerck LS, Stevens WJ, Vrints CJ. Cytokines and immune activation in systolic heart failure: the role of Type D personality. Brain, behavior, and immunity. 2003 Aug 1;17(4):304-9.

12. Mols F, Holterhues C, Nijsten T, van de Poll-Franse LV. Personality is associated with health status and impact of cancer among melanoma survivors. European Journal of Cancer. 2010 Feb 1;46(3):573-80.

13. Paykel ES, Myers JK, Dienelt MN, Klerman GL, Lindenthal JJ, Pepper MP. Life events and depression: A controlled study. Archives of general Psychiatry. 1969 Dec 1;21(6):753-60.

14. Eysenck HJ. Manual of the Eysenck Personality Questionnaire (adult and junior) 1975.

15. Floyd M, Garfield A, LaSota MT. Anxiety sensitivity and worry. Personality and Individual Differences. 2005 Apr 1;38(5):1223-9.

16. Zoljanahi E. \& Vafaie M. Relationship between type-d personality and behavioral inhibition and activation systems. Journal of Psychology (Tabriz University) 2006; 1(2-3): 123-144(Persian).

17. Baraheni MM. A psychometric study of Eysenk personality Inventory on a Sample of Iranian college students. InThe international Symposium on epidemiological studies in psychometric 1976.

18. Holmes TH, Rahe RH. The social readjustment rating scale. Journal of psychosomatic research. 1967.

19. VAFAEI B. Evaluation of the relation between life stresses and blood neoplastic diseases in males and females aged between 30 and 50 .

20. Mirzaie SN, Shams Alizadeh N. Prevalence rate of suicidal thoughts and its related factors in the medical students in Kurdistan University of Medical Sciences. Scientific Journal of Kurdistan University of Medical Sciences. 2013 May 10;18(1):18-26.

21. Luecken LJ, Compass BE. Sress, coping and immune function in breast cancer. Society of Behavioral Medicine. 2002; 4(4): 336-4.

22. Hashemi T, Peymannia B. The relationship between (D) type of personality, and perceived stress with health behaviors in women with breast cancer.

23. De Clercq B, De Fruyt F, Koot HM, Benoit Y. Quality of life in children surviving cancer: A personality and multi-informant perspective. Journal of pediatric psychology. 2004 Dec 1;29(8):579-90. 
24. Snowling MJ, Hulme C. Annual Research Review: The nature and classification of reading disorders-a commentary on proposals for DSM-5. Journal of Child Psychology and Psychiatry. 2012 May;53(5):593607.

25. Nakaya N, Tsubono Y, Nishino Y, Hosokawa T, Fukudo S, Shibuya D, Akizuki N, Yoshikawa E, Kobayakawa M, Fujimori M, Saito-Nakaya K. Personality and cancer survival: the Miyagi cohort study. British Journal of Cancer. 2005 Jun;92(11):2089-94.

26. Bijari H, Ghanbari BA, Aghamohammadian HR,Homaii F. Effectiveness of group therapy based on logotherapy approach to increasing the life expectancy for women with breast cancer. Studies in Education and Psychology 1388; 10(1): 171-84.

27. Zvolensky MJ, Schmidt NB, Bernstein A, Keough ME. Risk-factor research and prevention programs for anxiety disorders: A translational research framework. Behaviour Research and Therapy. 2006 Sep 1;44(9):1219-39.

28. Kashdan TB, Barrios V, Forsyth JP, Steger MF. Experiential avoidance as a generalized psychological vulnerability: Comparisons with coping and emotion regulation strategies. Behaviour research and therapy. 2006 Sep 1;44(9):1301-20. 